九州大学学術情報リポジトリ

Kyushu University Institutional Repository

\title{
Lack of Prezygotic Reproductive Isolation between Rhododendron eriocarpum and R. indicum ; Overlapping Flowering Phenology and Cross Compatibility
}

Tagane, Shuichiro

Graduate School of Bioresource and Bioenvironmental Sciences, Kyushu University

Hiramatsu, Michikazu

Faculty of Agriculture, Kyushu University

Okubo, Hiroshi

Faculty of Agriculture, Kyushu University

https://doi.org/10.5109/9341

出版情報: 九州大学大学院農学研究院紀要. 52 (2)，pp. 345-348，2007-10-29. Faculty of Agriculture, Kyushu University

バージョン：

権利関係 : 


\title{
Lack of Prezygotic Reproductive Isolation between Rhododendron eriocarpum and $R$. indicum; Overlapping Flowering Phenology and Cross Compatibility
}

\author{
Shuichirou TAGANE ${ }^{1 *}$, Michikazu HIRAMATSU \\ and Hiroshi OKUBO \\ Laboratory of Horticultural Science, Division of Agricultural Botany, Department of Plant Resources, \\ Faculty of Agriculture, Kyushu University, Fukuoka, 812-8581, Japan \\ (Received June 30, 2007 and accepted July 17, 2007)
}

\begin{abstract}
Flowering phenology in Rhododendron eriocarpum and R.indicum in Yakushima Island and its surrounding islands and cross compatibility between the species were investigated. We found that their flowering periods partially overlapped from May to early June. The flowering peaks of the riverside populations were variable and longer than those of the seaside populations where the flowering patterns synchronized. In artificial intra- and inter-specific outcross experiment, $>60 \%$ crosses were successful. Weak self-incompatibility was observed in the both species. Their cross compatibility has been maintained in their presumptive hybrids. These results indicate that there is little prezygotic reproductive isolation between the two species and the lack of such reproductive isolation is likely to have contributed the diversification of 'Satsuki' cultivars.
\end{abstract}

\section{INTRODUCTION}

The genus Rhododendron L. (Ericaceae) including over 1000 species is widely distributed in the Northern Hemisphere and subdivided into eight subgenera and 12 sections (Champberlain et al., 1996), among which fifty species are native to Japan (Yamazaki, 1996). The species in the section Tsutsusi of subgenus Tsutsusi are the most important evergreen azaleas and used as resources of ornamentals. Satsuki azalea (Rhododendron indicum (L.) Sweet) is one of them and used for such many horticultural purpose as gardening, hedge, greening and Bonsai. It is said that there are more than 2,000 cultivars and that the cultivars contain natural hybrids with $R$. eriocarpum (Hayata) Nakai, because the distribution of the two species overlaps in Yakushima Island and there are abundant morphological variations (Kunishige and Kobayashi, 1980).

Rhododendron eriocarpum and $R$. indicum are diploid $(2 \mathrm{n}=26)$ evergreen azaleas (section Tsutsusi), 0.5-1.5 m tall shrubs and endemic to Japan (Yamazaki, 1996). Rhododendron eriocarpum is distributed in Tokara archipelago, Mishima archipelago, Tanegashima Island, Yakushima Island and the southernmost part of Satsuma Peninsula of Kyushu Island, the southwestern mainland of Japan, while $R$. indicum is in Kinki and Chubu districts in the central part of Honshu Island, the largest mainland of Japan and Yakushima Island. They are morphologically distinguishable by corolla color (light purple in $R$. eriocarpum v.s. deep red in $R$. indicum), number of stamina (ten in $R$. eriocarpum v.s. five in $R$. indicum) and leaf shape (obovate, broadly

\footnotetext{
1 Laboratory of Horticultural Science, Division of Agricultural Botany, Department of Plant Resources, Graduate School of Bioresource and Bioenvironmental Sciences, Kyushu University, Fukuoka 812-8581, Japan

* Corresponding author (E-mail: crassa@agr.kyushu-u.ac.jp)
}

obovate in $R$. eriocarpum v.s. lanceolate in $R$. indicum) (Yamazaki, 1996). Rhododendron eriocarpum grows on a sunny rocky stretch and forest margin in seaside, while $R$. indicum grows along mountain streams and sometimes on an open summit in Yakushima Island.

The degree of reproductive isolation among related species is an important factor influencing genetic integrity of a species and the probability of the formation of hybrids (Levin, 1978; Grant, 1981; Harrison, 1993; Avise, 1994; Arnold, 1997; Alarcón and Campbell, 2000; Mráz et al., 2005). There is no knowledge on reproductive isolation mechanisms for $R$. eriocarpum and $R$. indicum in Yakushima Island. In this study, we investigated flowering phenology and cross-compatibility of the two species to determine whether they work as prezygotic barriers or not.

\section{MATERIALS AND METHODS}

\section{Study populations}

Six (Ys1-2, 4-7), 11 (Yr1-8) and two (Ym1-2) populations of Yakushima Island were selected for the study. They are located in seaside forest margin, along rapid mountain streams and in open summits, respectively (Fig. 1B, Table 1). Two additional populations of $R$. eriocarpum in Nakanoshima Island (NKN) and Kuchinoerabujima Island (KCN) were supplied for artificial cross experiment (Fig. 1A, Table 1).

Individuals in NKN and KCN where only $R$. eriocarpum is distributed were morphologically identified as $R$. eriocarpum. All seaside populations in Yakushima Island seemed to contain hybrids and can be roughly divided into two groups; Ys1-2 and 4-5 are consisted of the individuals morphologically rather similar to $R$. eriocarpum (Eriocarpum-like type), whereas Ys6-7 are consisted of individuals rather similar to $R$. indicum (Indicum-like type). All riverside and summit popula- 
tions were judged to be $R$. indicum. The riverside population of Yr7 was, however, divided into four subpopulations Yr7(1)-(4) by $200 \mathrm{~m}$ distance interval from Torohki fall at the river mouth along Tainoko-river, because Yr7 seemed to have contributed to the hybridization with a seaside population Ys6.

\section{Flowering pattern and fruit set under natural con- dition}

Flowering patterns and natural fruit sets of seven to 21 individuals of each population were observed in 2006 (Table 1, Fig. 1). Number of flowers was counted every two weeks from 18 April to 15 July. Flowering that occurred out of the observation period was excluded in phenology analysis. Number of mature fruits per total flowers was used for evaluation of fruiting success.

Pollinator visitation was investigated in four seaside populations (Ys1-2, Ys4 and Ys6) and three riverside populations (Yr3, Yr5 and Yr7) for about five to 10 plants in each population to examine the relationship to fruit set. Periods of observation varied from one to eight hours during daytime (from 9:00 to 16:00) in 2001 and 2003, because populations with lower pollinator frequency needed longer observation time.

\section{Artificial cross}

Plants raised from the cuttings of $R$. eriocarpum of Nakanoshima Island (NKN), Kuchinoerabujima Island (KCN), R. indicum (Yr6-7), Eriocarpum-like individuals (Ys4) and Indicum-like individuals (Ys6) were used. Self- and cross-pollinations were conducted in a plastic house shaded with black cloth in our experimental field in 2005, 2006 and 2007. Self pollination was conducted by hand with fresh pollen of the same plant. Flowers for cross pollination were emasculated before

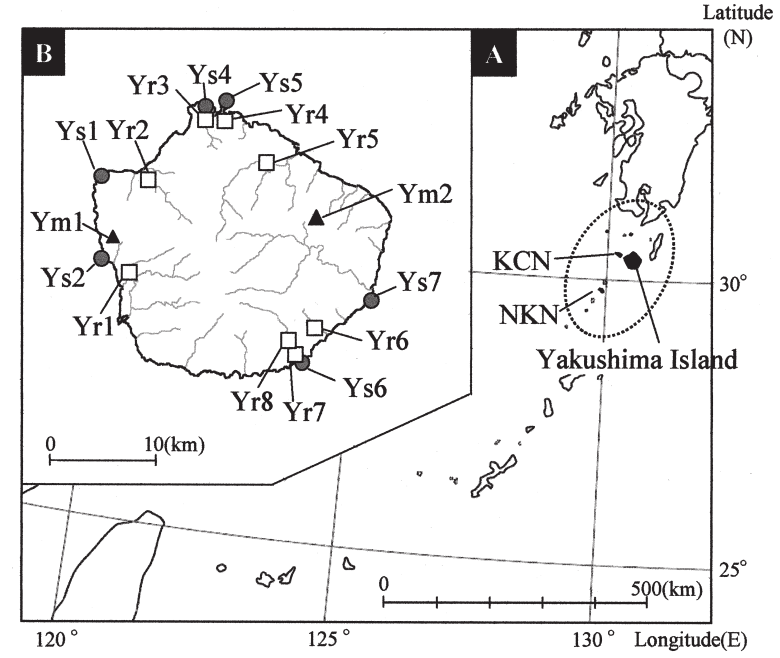

Fig. 1. Geographic distribution of Rhododendron populations investigated in this study. A, the location of Yakushima Island and two populations neighboring to Yakushima Island. A circle by dotted lines indicates the distribution of $R$. eriocarpum. $R$. indicum is distributed only in Yakushima Island. $B$, the location of populations in Yakushima Island. $\quad$; seaside populations, $\square$; riverside populations, $\boldsymbol{\Delta}$; summit populations. See Table 1 for abbreviation of population names.

Table 1. Geographic location of Rhododendron populations for the observations of fruit set and flowering patterns in this study

\begin{tabular}{|c|c|c|c|c|c|c|c|}
\hline \multirow{2}{*}{$\begin{array}{l}\text { Population } \\
\text { ID }\end{array}$} & \multirow[t]{2}{*}{ Location } & \multirow{2}{*}{$\begin{array}{l}\text { Latitude } \\
\text { (N) }\end{array}$} & \multirow{2}{*}{$\begin{array}{l}\text { Longtitude } \\
\text { (E) }\end{array}$} & \multirow{2}{*}{$\begin{array}{l}\text { Altitude } \\
\text { (m) }\end{array}$} & \multirow[t]{2}{*}{ Habitat } & \multicolumn{2}{|c|}{$\begin{array}{l}\text { No. of accessions for floweirng } \\
\text { pattern and fruit set observations }\end{array}$} \\
\hline & & & & & & individuals & flowers/individuals \\
\hline $\mathrm{NKN}$ & Nakanoshima Isl. & $29^{\circ} 51^{\prime}$ & $129^{\circ} 51^{\prime}$ & Unknown & volcanic slope & - & - \\
\hline $\mathrm{KCN}$ & Kuchinoerabujima Isl. & $30^{\circ} 26^{\prime}$ & $130^{\circ} 13^{\prime}$ & Unknown & volcanic slope & - & - \\
\hline Ys1 & Nagata cape, Yakushima Isl. & $30^{\circ} 23^{\prime}$ & $130^{\circ} 22^{\prime}$ & 30 & seaside & 15 & 36.1 \\
\hline Ys2 & Tategami, Yakushima Isl. & $30^{\circ} 19^{\prime}$ & $130^{\circ} 23^{\prime}$ & 20 & seaside & 20 & 33.6 \\
\hline Ys4 & Ooura, Yakushima Isl. & $30^{\circ} 27^{\prime}$ & $130^{\circ} 28^{\prime}$ & 10 & seaside & 18 & 55.8 \\
\hline Ys5 & Yahazu cape, Yakushima Isl. & $30^{\circ} 28^{\prime}$ & $130^{\circ} 29^{\prime}$ & 10 & seaside & 19 & 44.4 \\
\hline Ys6 & Torohki fall, Yakushima Isl. & $30^{\circ} 15^{\prime}$ & $130^{\circ} 35^{\prime}$ & 3 & seaside & 16 & 9.6 \\
\hline Ys7 & Harutahama, Yakushima Isl. & $30^{\circ} 17^{\prime}$ & $130^{\circ} 38^{\prime}$ & 5 & seaside & 12 & 32.1 \\
\hline Ym1 & Hidsukushi, Yakushima Isl. & $30^{\circ} 19^{\prime}$ & $130^{\circ} 23^{\prime}$ & 410 & summit & 11 & 9.5 \\
\hline Ym2 & Mt. Aikodake, Yakushima Isl. & $30^{\circ} 21^{\prime}$ & $130^{\circ} 36^{\prime}$ & 1235 & summit & 18 & 46.3 \\
\hline Yr1 & Ookawa River, Yakushima Isl. & $30^{\circ} 18^{\prime}$ & $130^{\circ} 25^{\prime}$ & 10 & riverside & 20 & 19.5 \\
\hline Yr2 & Nagata River, Yakushima Isl. & $30^{\circ} 23^{\prime}$ & $130^{\circ} 26^{\prime}$ & 30 & riverside & 21 & 21.8 \\
\hline Yr3 & Isso River, Yakushima Isl. & $30^{\circ} 26^{\prime}$ & $130^{\circ} 28^{\prime}$ & 40 & riverside & 17 & 17.8 \\
\hline Yr4 & Nunobiki fall, Yakushima Isl. & $30^{\circ} 26^{\prime}$ & $130^{\circ} 29^{\prime}$ & 100 & riverside & 19 & 21.5 \\
\hline Yr5 & Miyanoura River, Yakushima Isl. & $30^{\circ} 24^{\prime}$ & $130^{\circ} 32^{\prime}$ & 20 & riverside & 20 & 26.4 \\
\hline Yr6 & Otakumi River, Yakushima Isl. & $30^{\circ} 16^{\prime}$ & $130^{\circ} 36^{\prime}$ & 300 & riverside & 15 & 30.2 \\
\hline $\operatorname{Yr} 7(1)$ & Tainoko River, low, Yakushima Isl. & $30^{\circ} 15^{\prime}$ & $130^{\circ} 35^{\prime}$ & 56 & riverside & 7 & 7.6 \\
\hline $\operatorname{Yr} 7(2)$ & Tainoko River, low, Yakushima Isl. & $30^{\circ} 15^{\prime}$ & $130^{\circ} 35^{\prime}$ & 41 & riverside & 19 & 21.6 \\
\hline $\operatorname{Yr} 7(3)$ & Tainoko River, low, Yakushima Isl. & $30^{\circ} 15^{\prime}$ & $130^{\circ} 35^{\prime}$ & 24 & riverside & 14 & 27.4 \\
\hline $\operatorname{Yr} 7(4)$ & Tainoko River, low, Yakushima Isl. & $30^{\circ} 15^{\prime}$ & $130^{\circ} 35^{\prime}$ & 18 & riverside & 11 & 29.8 \\
\hline Yr8 & Tainoko River middle, Yakushima Isl. & $30^{\circ} 15^{\prime}$ & $130^{\circ} 34^{\prime}$ & 340 & riverside & 18 & 30.6 \\
\hline Average & & & & & & 33 & 27.5 \\
\hline Total & & & & & & 620 & 521.6 \\
\hline
\end{tabular}


anthesis. All the flowers for the crossings were covered by paper bags before anthesis and re-bagged after pollination treatments. Fruit set was determined four months in 2005 and 2006, and 40 days in 2007 after pollination.

\section{RESULTS AND DISCUSSION}

\section{Flowering pattern and fruit set under natural con- ditions}

Flowering patterns synchronized in the seaside populations (Ys1-2 and Ys4-7) that bloomed from late April to mid June with a flowering peak in May (Fig. 2). Flowering peak of the riverside populations (Yr1-8) varied ranging from mid May to mid July and the period was longer than that in the seaside populations. Plants of the summit populations flowered later than those of the other populations. Ym2 individuals, which grow at $1200 \mathrm{~m}$ altitude, started flowering in early May and the flowering lasted until late July. It is noticeable that the flowering periods among three different habitats overlap during more than two months in spite that their patterns were variable.

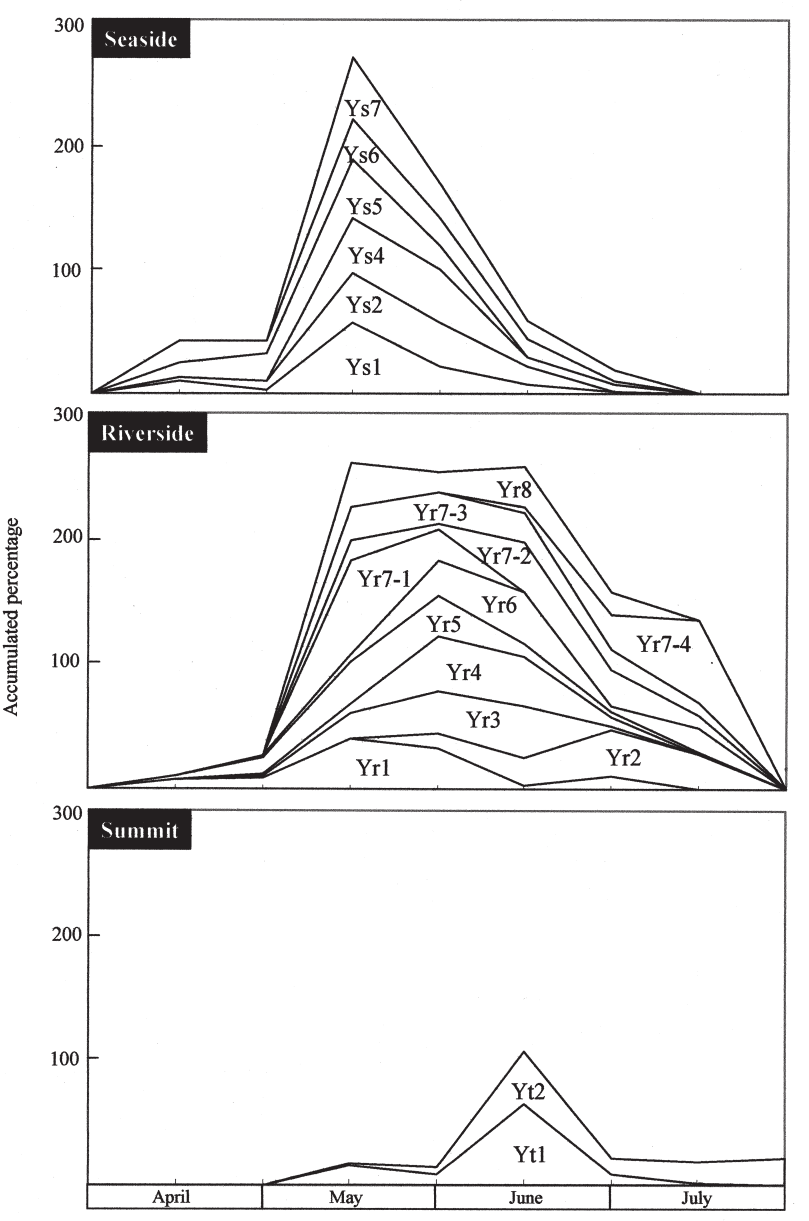

Fig. 2. Flowering patterns in seaside, riverside and summit Rhododendron populations. See Table 1 for abbreviation of population names. One diagram expresses the changes in flowering percentage in one population. (number of flowers at the time of observation conducted every two weeks)/(total number of flowers throughout the full observation periods $) \times 100$.
Variations in flowering patters may be due to the differences in microhabitats which strongly influence plant phenology (Tarasjev, 1997). Individuals in the seaside populations grow in a rather uniform environment on sunny rocky stretch near the sea, whereas those in the riverside populations grow in more various environments; they grow not only on sunny moisture rocks nearby the stream but also under a shaded forest edge along the stream, and the direction of valley also influences habitat's daylight and temperature. Four subpopulations, Yr7 (1)-(4) had different flowering patterns, despite that they grew closely with only $200 \mathrm{~m}$ distance. The longer flowering period of riverside $R$. indicum seems to be the reproductive strategy as a rheophyte to avoid blooming flowers from being washed away by frequent floods as suggested by Van Steenis (1981) and Kato (2003).

Average fruit set in Eriocarpum-like seaside populations (Ys1-2 and 4-5) was about 59\%, while those of Indicum-like seaside populations (Ys6-7) and of riverside populations (Yr1-8) were around 22\%. Summit populations (Ym1-2) showed the lowest fruit set of 3.6\% (Fig. 3). Number of pollinators per hour was 9.9 in Eriocarpum-like seaside populations (Ys1-2 and Ys4-5), 2.7 in Indicum-like seaside populations (Ys6-7) and 1.4 in riverside populations (Fig. 3). Generally, pollinator visitation highly enhanced fruit set in entomophilous flowers (Kudo, 1993; Ng and Corlett, 2000). Considering that both species and presumptive hybrids showed high fertility in artificial cross experiment (see below, Table2), low pollinator frequency seems to cause lower fruit set of Indicum-like seaside population (Ys6-7) and riverside populations.

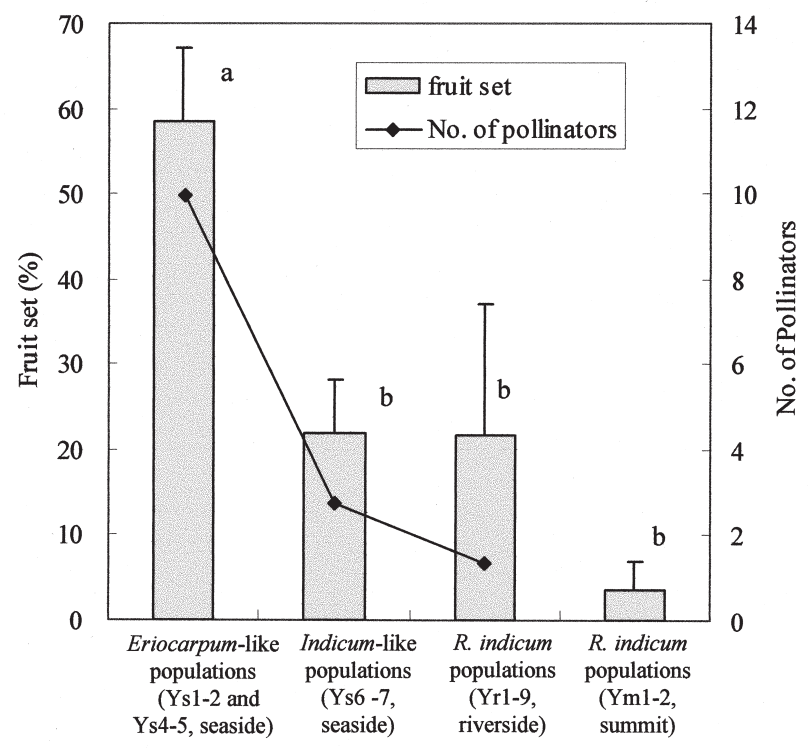

Fig. 3. Average fruit set (\%) and number of observed pollinators. Pollinator frequencies represent the results from observation in Ys1, Ys2 and Ys4 for Eriocrapum-like hybrids, Ys6 for Indicum-like hybrids, and Yr5 for riverside $R$. indicum. Pollinator observation was not conducted in summit populations. Different letters mean significant difference $(\mathrm{P}<0.05)$ based on Tukey's HSD (honestly significant difference) test. 
Table 2. Percentage of fruit set in self- and cross-pollination treatments. Number of fruits formed and number of flowers tested are shown in parentheses

\begin{tabular}{|c|c|c|c|c|c|}
\hline \multirow{3}{*}{ Cross } & \multirow{3}{*}{ Seed parent } & \multicolumn{4}{|c|}{ Pollen parent } \\
\hline & & \multirow{2}{*}{$\begin{array}{l}\text { R. eriocarpum } \\
\text { NKN, KCN }\end{array}$} & \multicolumn{2}{|c|}{ Hybrid poplations } & \multirow{3}{*}{$\begin{array}{c}\text { R. indicum } \\
\text { Yr6, Yr7 } \\
37.5(3 / 8)\end{array}$} \\
\hline & & & Ys4 & Ys6 & \\
\hline self & & $40(2 / 5)$ & $20 \quad(2 / 5)$ & $20 \quad(2 / 10)$ & \\
\hline \multirow[t]{4}{*}{ outcross } & R. eriocarpum (NKN, KCN) & $100(7 / 7)$ & $(2 / 2)$ & $100 \quad(5 / 5)$ & $91.7(11 / 12)$ \\
\hline & Eriocarpum-like hybrids (Ys4) & - & $(3 / 4)$ & $(4 / 5)$ & $60 \quad(3 / 5)$ \\
\hline & Indicum-like hybrids (Ys6) & $100(2 / 2)$ & $83.3(5 / 6)$ & $100(1 / 1)$ & $75 \quad(3 / 4)$ \\
\hline & R. indicum (Yr6, Yr7) & $80(4 / 5)$ & $100 \quad(5 / 5)$ & $83.3(5 / 6)$ & $92.3(12 / 13)$ \\
\hline
\end{tabular}

\section{Artificial cross}

Intra- and interspecific crosses of the two parent species showed $>80 \%$ fruit set (Table 2 ). Fruit sets of the presumptive hybrid populations, Ys4 and Ys6, were comparable to that of parent species in crosses with parent species and within the populations. These results indicate that hybrids maintain their fertility and there is no effective isolation mechanism in fertilization between the two species even after interspecific hybridization. Once $\mathrm{F}_{1}$ hybrids are established, they can be either a maternal or paternal donor and their backcross with sympatric parent species would form offspring with morphologically variable traits.

Lower fruit set by selfing than that by outcross suggest weak self-incompatibility of the both species. Self-incompatibility is one of the mechanisms that have evolved to encourage outbreeding in flowering plants (De Nettancourt, 1977) and known for some closely related Rhododendron species of section Tsutsusi (Yamaguchi, 1980; Ng and Corlett, 2000).

\section{ACKNOWLEDGMENTS}

We thank Mr. Kazuyuki Sakan, Mrs. Tomie Sakan and Mr. Toshihiro Saitoh live in Yakushima Island for great help in our field survey.

\section{REFERENCES}

Alarcón, R. and D. R. Campbell 2000 Absence of conspecific pollen advantage in the dynamics of an Ipomopsis (Polemoniaceae) hybrid zone. Am. J. Bot., 87: 819-824

Arnold, M. L. 1997 Natural Hybridization and Evolution. Oxford University Press, Oxford

Avise, C. J. 1994 Molecular Markers, Natural History and Evolution. Chapman \& Hall, New York

Champberlain, D. F., R. Hyam, G. Argent, G. Fairwether and K. S.
Walter 1996 The Genus Rhododendron, its Classification and Synonymy. Roy. Bot. Gard. Edinburgh, Edinburgh

De Nettancourt, D. 1977 Incompatibility in Angiosperms. Springer, Berlin, Heidelberg, New York

Grant, V. 1981 Plant Speciation. Columbia University Press, New York

Harrison, T. 1993 Cladistic concepts and the species problem in hominoid evolution. In "Species, Species Concepts, and Primate Evolution", ed. by W. H. Kimbel and L. B. Martin, Plenum Press, New York, pp. 345-371

Kaku, S. 1993 Monitoring stress sensitivity by water proton NMR relaxation times in leaves of azaleas that originated in different ecological habitats. Plant Cell Physiol., 34: 535-541

Kato, M. 2003 Evolution and adaptation in the rheophytes. Bunrui, 3: 107-122

Kudo, G. 1993 Relationships between flowering time and fruit set of the entomophilous alpine shrub, Rhododendron aureum (Ericaceae), inhabiting snow patches. Am. J. Bot., 80: 1300-1304

Kunishige, M. and Y. Kobayashi 1980 Chromatographic identification of Japanese azalea species and their hybrids. In "Contributions toward a Classification of Rhododendron", ed. by J. L. Luteyn and M. E. O'Brien, The New York Botanical Garden, New York, pp. 277-287

Levin, D. A. 1978 The origin of isolating mechanisms in flowering plants. Evol. Boil., 11: 185-317

Mráz, P., J. Chrtek, J. Fehrer and I. Plackova 2005 Rare recent natural hybridization in Hieracium s. str-evidence from morphology, allozymes, and chloroplast DNA. Plant Syst. Evol., 255: 177-192

Ng, S. C. and R. T. Corlett 2000 Comparative reproductive biology of the six species of Rhododendron (Ericaceae) in Hong Kong, South China. Can. J. Bot., 78: 221-229

Tarasjev, A. 1997 Flowering phenology in natural populations of Iris pumila. Ecography, 20: 48-54

Van Steenis, C. G. G. J. 1981 Rheophytes of the World. Sijthoff and Noordhoff, Alphen aan den Rijn

Yamaguchi, S. 1980 Field test of self-incompatibility in Rhododendron kiushianum. Incompat. Newlett., 12: 16-23

Yamazaki, T. 1996 A Revision of the Genus Rhododendron in Japan, Taiwan, Korea and Sakhalin. Tsumura Laboratory, Tokyo 